\title{
Trace element and nutrient accumulation in sunflower plants two years after the Aznalcóllar mine spill
}

\author{
P. Madejón ${ }^{\text {a,*, J.M. Murilloa, T. Marañón }}{ }^{\mathrm{a}}$, F. Cabrera ${ }^{\mathrm{a}}$, M.A. Soriano ${ }^{\mathrm{b}}$
}

aIRNAS, CSIC, Instituto de Recursos Naturales y Agrobiología de Sevilla, Reina Mercedes Campus, P.O. Box 1052, Sevilla 41080, Spain

bescuela Técnica Superior de Ingenieros Agrónomos y Montes, University of Córdoba, Apartado 3048, Córdoba 14080, Spain

\begin{abstract}
The failure of a tailing pond dam at the Aznalcóllar pyrite mine (SW Spain) in April 1998 released a toxic spill affecting approximately 4300 ha along the Agrio and Guadiamar valleys. Two years later, we have studied yield and concentration of mineral nutrients and trace elements in sunflower plants grown in the spill-affected soil, and in an adjacent unaffected soil as comparison. The study has been carried out in plants at seedling (V4) and mature (R8) stages. Shoot and root biomass of sunflower seedlings was significantly smaller in the affected soil than in the unaffected soil, but there was no significant difference at the mature stage. Oil production was greater in the spillaffected plants. We have not detected any 'fertilising' effect caused by the acid waters of the spill on the main nutrient (N, P and Ca) acquisition, as documented in 1998 for sunflower plants flooded by the spill. Sunflower plants growing in the spill-affected soil reached adequate levels of nutrients. None of the trace elements measured-As, Cd, $\mathrm{Cu}, \mathrm{Pb}$ and $\mathrm{Tl}$-reached levels either phytotoxic or toxic for humans or animals in seeds and the above-ground part of the spill-affected plants. We evaluate the potential use of sunflower plants for phytoremediation. The potential for phytoextraction is very low; however, it may be used for soil conservation. The production of oil (usable for industrial purposes) may add some value to this crop.
\end{abstract}

Keywords: Guadiamar river; Heavy metals; Helianthus annuus; Pyrite tailings

\section{Introduction}

The failure of a tailing pond dam at the pyrite mine of Aznalcóllar (S. Spain) in April 1998 released a toxic spill of ca. $5 \times 10^{6} \mathrm{~m}^{3}$, affecting a total of 4286 ha along the Agrio and Guadiamar river valleys. The slurry comprised of approximately $2 \times 10^{6} \mathrm{~m}^{3}$ of tailing (solid phase) and 3$4 \times 10^{6} \mathrm{~m}^{3}$ of polluted acid water. Soil pollution by tailings tended to diminish below the $10-\mathrm{cm}$ depth (Simón et al., 1999), but polluted water entered deeper into the soil (Ayora et al., 2001). A long strip, approximately $300-400-\mathrm{m}$ wide and $40 \mathrm{~km}$ in length, was covered by a layer of toxic black sludge $2-30-\mathrm{cm}$ thick on both sides of the river channel (Grimalt et al., 1999).

The river floodplain was occupied mainly by croplands and orchards. The effects of the spill on crop plants varied with location. Many plants near 
the river channel were washed out or completely submersed by the spill and killed; others, more distant from the channel, had immersed stem bases but continued to grow and set seeds. We documented (in June 1998, 2 months after the accident) the effects of the spill pollution on sunflower plants growing in the affected area; germination and early growth of those plants took place before the soil was polluted, and plants were at V8 stage at the moment of the accident (Murillo et al., 1999). We will refer hereafter to that study as the 1 st scenario. The acid waters of the spill probably dipped the bulk, developed root system of the sunflower. Moistening and acidification of the rhizosphere could enhance the nutrient uptake mechanism of the crop, inducing a 'fertilising' effect (Murillo et al., 1999).

Two years after the mine accident, in the springsummer of 2000 (which we will refer to as the 2nd scenario), the situation had changed on the spill-affected land. An emergency soil clean-up procedure had been quickly started after the accident, and the sludge covering the ground was mechanically removed from most of the affected land. Despite those clean-up operations, the affected zone continued to have a consistent level of pollution by trace metals, with a fairly irregular distribution (Ayora et al., 2001; Galán et al., 2002). Thus, the sunflower plants collected in 2000 and studied here (2nd scenario) had to germinate and grow in polluted soils, which could affect young rootlet performance from the early stages.

Cultivation of food crops in the spill-affected area was prohibited by law following the accident. Affected lands were compulsorily purchased by the Regional Government, and a large-scale restoration plan-The Green Corridor-was initiated. This Corridor has been planted with native trees and shrubs to serve as an ecological belt (Junta de Andalucía, 2001) connecting nature reserves in the lowlands (Doñana National Park) and the mountains (Sierra Norte Natural Park). Within the Corridor, several controlled experimental plots have been devoted to the growth of plants for potential use in phytoremediation; one of the selected plants was the sunflower.

The sunflower has a reasonable tolerance to heavy metals. It has been used for rhizofiltration because it has a high root uptake of metals but a low efficiency in their translocation from root to shoot (Saxena et al., 1999; Kamnev and Van der Lelie, 2000). It has also been proposed for cleaning up soils contaminated by Zn (Van der Lelie et al., 2001). This crop can also improve the economic balance of phytoremediation via the potential yield of oil production (though this must be used for industrial purposes).

The present study has the following aims: (1) to determine the concentration of trace elements in sunflower plants growing in polluted soils, at two developmental stages-seedling and mature plant - with particular focus on the possible toxicity level in the seeds; (2) to document the performance and pollution status of sunflower plants growing in the spill-affected soils 2 years after the accident (2nd scenario), and to compare these results with those obtained in plants directly flooded by the spill in 1998 (1st scenario); and (3) to evaluate the potential use of sunflower in the phytoremediation of polluted soils.

\section{Materials and methods}

\subsection{Crop cultivation}

We selected the hybrid sunflower (Helianthus annuus L., cv. 'Sambro') for the experimental cultivation under rainfed conditions, following the normal practices in Andalucía (SW Spain) for this crop.

Two experimental plots of approximately 5000 $\mathrm{m}^{2}$ were set up. One was located on a silty clay loam soil ( $\mathrm{pH} 7.8)$ affected by the spill, in the Green Corridor ( $\left.37^{\circ} 27^{\prime} 42.9^{\prime \prime} \mathrm{N} 6^{\circ} 12^{\prime} 39^{\prime \prime} \mathrm{W}\right)$. A second plot, on non-affected clay loam soil ( $\mathrm{pH}$ 7.9) for comparative purposes, was located nearby on the Soberbina farm (approx. $2 \mathrm{~km}$ away, $37^{\circ}$ $\left.27^{\prime} 31.3^{\prime \prime} \mathrm{N} \mathrm{6} 6^{\circ} 12^{\prime} 13.8^{\prime \prime} \mathrm{W}\right)$.

A seedbed was prepared in each plot by chiselling. They were fertilised with approximately 700 $\mathrm{kg} \mathrm{ha}{ }^{-1}$ of a complex fertiliser $15 \mathrm{~N}-15 \mathrm{P}_{2} \mathrm{O}_{5}-$ $15 \mathrm{~K}_{2} \mathrm{O}$ before seeding, and with a top-dressing of $55 \mathrm{~kg}$ urea-N ha ${ }^{-1}$ after seeding. Sowing was carried out in mid-February 2000 at a final plant density of approximately 60000 plants ha ${ }^{-1}$. Herbicide (glyphosate) was applied when needed. 


\subsection{Plant and soil sampling}

During the period of crop cultivation, some individual plants were collected at different growth stages to study the temporal changes in mineral uptake and allocation. The growth stages are described according to Schneiter and Miller (1981): V4 (vegetative stage; four true leaves at least $4 \mathrm{~cm}$ in length) and R8 (reproductive stage; back of head is yellow but the bracts remain green).

The first sampling was carried out at the V4 stage, 1 month after sowing. Nine seedlings were selected at random in one area of approximately $10 \mathrm{~m}^{2}$, and this sampling was repeated at three points approximately $20 \mathrm{~m}$ apart within the plot (making a total of three lots of seedlings per plot). Selected seedlings were excavated to take out the root system as complete as possible, thereby collecting the whole plant. The second sampling was carried out approximately 130 days after seeding; plants were at the R8 stage. Three complete plants were randomly selected in a $10-\mathrm{m}^{2}$ area, their height was measured, and they were excavated to take out the whole plant. This procedure was repeated three times within each plot (total of nine plants per plot).

Collected plants were immediately transported to the laboratory and there weighed (fresh wt.). They were partitioned for analysis into roots, stems and expanded leaves (stage V4), and roots, stems, petioles, blades, head and seeds (stage R8). All these fractions were briefly washed (15 s approx.) with a solution of phosphate-free detergent, then with a $0.1 \mathrm{~N} \mathrm{HCl}$ solution, and finally with distilled water. They were dried at $70{ }^{\circ} \mathrm{C}$, weighed and ground to pass through a $500-\mu \mathrm{m}$ stainless steel sieve.

The seed weight was calculated by weighing three lots of 25 seeds per plant. Oil content of the seeds (achenes) was determined by extraction with petroleum ether on a fresh-matter basis.

Soil samples were taken during the first plant harvest (1 month after sowing), at $0-25$ - and 25$40-\mathrm{cm}$ depths, using a spiral auger of $2.5-\mathrm{cm}$ diameter. These samples were taken at the same point where each lot of seedlings was harvested (total of three soil samples per plot). Soil samples were oven-dried at $40{ }^{\circ} \mathrm{C}$ and crushed to pass through a 2-mm sieve, and then ground to $<60$ $\mu \mathrm{m}$ for determination of $\mathrm{S}$ and trace elements.

\subsection{Chemical analyses}

Plant material was analysed for $\mathrm{N}$ by Kjeldahl digestion. Mineral nutrients ( $\mathrm{P}, \mathrm{K}, \mathrm{S}, \mathrm{Ca}$ and $\mathrm{Mg}$ ) and trace elements (As, $\mathrm{Cd}, \mathrm{Cu}, \mathrm{Fe}, \mathrm{Mn}, \mathrm{Pb}, \mathrm{Tl}$ and $\mathrm{Zn}$ ) were extracted by wet oxidation with concentrated $\mathrm{HNO}_{3}$ under pressure in a microwave digester. Analysis of mineral nutrients and $\mathrm{Fe}$ and $\mathrm{Mn}$ in the extracts thus obtained was performed by ICP-OES (inductively coupled plasma-optical emission spectrometry). Analysis of trace elements (As, $\mathrm{Cd}, \mathrm{Cu}, \mathrm{Pb}, \mathrm{Tl}$ and $\mathrm{Zn}$ ) was performed by ICP-MS (inductively coupled plasma-mass spectrometry).

The accuracy and precision of the analytical method were assessed by carrying out analyses of two BCR (Community Bureau of Reference) reference samples: CRM 279 (sea lettuce) and CRM 281 (ryegrass) (Griepink and Muntau, 1987, 1988). The values obtained by ICP-MS (except for $\mathrm{Mn}$, for which the ICP-OES value is shown), and the comparative certified values for the same reference material, are shown in Table 1 . Concentrations of macronutrients (measured by ICP-OES) in BCR samples are only indicative.

Soil samples (fraction $<60 \mu \mathrm{m}$ ) were analysed for $\mathrm{S}$ and trace elements by ICP-OES after digesting the samples with a mixture of concentrated $\mathrm{HNO}_{3}$ and $\mathrm{HCl}$ ('aqua regia'); these values are referred to as 'total' concentration. Available concentration of trace elements was determined by ICP-OES after extracting the samples with $0.05 \mathrm{M}$ EDTA solution. Total and available concentrations of the elements in soil are given on a dry-weight basis.

\subsection{Statistical analyses}

A Student's $t$-test was used to assess differences in concentration of trace elements in plants between the unaffected and the spill-affected plot. A significance level of $P<0.05$ was used through the study. When the normality test failed (using the Kolmogorov-Smirnov test), the variables were 


\section{Table 1}

Analysis of BCR reference samples (for macronutrients, mean value \pm S.D., $\mathrm{mg} \mathrm{g}^{-1}$ dry matter; for trace elements, mean values $\pm 95 \%$ confidence interval, $\mathrm{mg} \mathrm{kg}^{-1}$ dry matter $)^{\mathrm{a}}$

\begin{tabular}{|c|c|c|c|c|}
\hline \multirow[t]{2}{*}{ Element } & \multicolumn{2}{|c|}{ CRM 279 (sea lettuce) } & \multicolumn{2}{|c|}{ CRM 281 (ryegrass) } \\
\hline & Certified & Experimental & Certified & Experimental \\
\hline $\mathrm{N}$ & $(20.5 \pm 0.4)$ & $17.0 \pm 0.7$ & $(33.2 \pm 0.5)$ & $31.7 \pm 1.3$ \\
\hline$P$ & $(1.80 \pm 0.04)$ & $1.50 \pm 0.08$ & $(2.30 \pm 0.05)$ & $2.15 \pm 0.08$ \\
\hline K & $(13.9 \pm 0.9)$ & $13.0 \pm 1.5$ & $(35.2 \pm 2.7)$ & $31.6 \pm 2.2$ \\
\hline $\mathrm{Ca}$ & $(27.4 \pm 1.1)$ & $30.8 \pm 4.1$ & $(7.20 \pm 0.09)$ & $6.75 \pm 0.13$ \\
\hline $\mathrm{Mg}$ & $(14.4 \pm 0.8)$ & $14.1 \pm 1.2$ & $(1.66 \pm 0.02)$ & $1.59 \pm 0.02$ \\
\hline As & $3.09 \pm 0.20$ & $2.69 \pm 0.11$ & $0.057 \pm 0.004$ & $0.118 \pm 0.014$ \\
\hline $\mathrm{Cd}$ & $0.274 \pm 0.022$ & $0.202 \pm 0.007$ & $0.120 \pm 0.003$ & $0.117 \pm 0.005$ \\
\hline $\mathrm{Cu}$ & $13.14 \pm 0.37$ & $11.63 \pm 0.73$ & $9.65 \pm 0.38$ & $9.76 \pm 0.09$ \\
\hline $\mathrm{Mn}$ & $(2030 \pm 31.5)$ & $1758 \pm 64.8$ & $81.6 \pm 2.6$ & $76.7 \pm 0.4$ \\
\hline $\mathrm{Pb}$ & $13.48 \pm 0.36$ & $12.47 \pm 1.09$ & $2.38 \pm 0.11$ & $2.29 \pm 0.07$ \\
\hline $\mathrm{Zn}$ & $51.3 \pm 1.2$ & $52.18 \pm 3.29$ & $31.5 \pm 1.4$ & $32.7 \pm 0.2$ \\
\hline
\end{tabular}

${ }^{a}$ Values in parentheses are indicatives. Experimental values are calculated from $n=6$ (sea lettuce) and $n=5$ (ryegrass). Indicative value for $\mathrm{N}$ in sea lettuce was determined by Dumas combustion.

logarithmically transformed; normality was then passed in all cases. The program SPSS (1999) for Windows was used for these statistical analyses.

\section{Results and discussion}

\subsection{Soil pollution}

The soil of the experimental plot located in the spill-affected area showed a significant level of pollution by trace elements (Table 2 ). In particular, the top layer $(0-25-\mathrm{cm}$ depth) had much higher concentrations of available $\mathrm{Zn}$ (18-fold), As (14fold) and Cd (8-fold) than the non-affected soil.

Sulfur content in the pyrite-originated sludge was extremely high, being within a range of 3540\% (Grimalt et al., 1999). Thus, a high S content in the soil may be indicative of the presence of sludge. In fact, the total S content of the topsoil layer in the spill-affected plot was ca. 23-fold that in the non-affected soil. The mean value of $S$ for the polluted soil $(0.46 \%)$ was outside the range for normal soils (maximum of $0.16 \%$ ) and ca. seven-fold that of the median $(0.07 \%)$ reported by Bowen (1979, see Table 2).

Iron content in the sludge was also high, but there were no significant differences in Fe concentration between affected and non-affected soils (data not shown). Manganese was not a polluting element in the sludge (Table 2). The available Mn concentration in the spill-affected soil (at 0-25$\mathrm{cm}$ depth) was significantly lower than in the nonaffected soil (Table 2).

Zinc was one of the highest-polluting elements in the sludge, having a concentration up to 11000 $\mathrm{mg} \mathrm{kg}{ }^{-1}$ (Cabrera et al., 1999). Consequently, available $\mathrm{Zn}$ in the topsoil of the spill-affected plot was approximately 18 -fold that at the non-affected site (Table 2). The high value of $\mathrm{Zn}$ total concentration $\left(209 \mathrm{mg} \mathrm{kg}^{-1}\right)$ in the same topsoil was almost double the median value for normal soils, although within the normal range (Bowen, 1979, see Table 2). Copper was another polluting element in the pyrite mine sludge, having a concentration of up to $2000 \mathrm{mg} \mathrm{kg}^{-1}$ (Cabrera et al., 1999). The pollution of the topsoil in the experimental plot was also significant, but less severe than for $\mathrm{Zn}$ : available $\mathrm{Cu}$ was almost double that in non-affected soil. Murillo et al. (1999) sampled the soil (removing the sludge layer) 2 months after the mine spill, and found a similar trend of higher available (DTPA-extracted) Zn (14-fold) and $\mathrm{Cu}$ (six-fold) in the affected soil than in the adjacent non-affected soil. Two years later, as shown by this study, the topsoil remains polluted.

Three potentially toxic elements had a high concentration in the mine sludge: lead $(8633 \mathrm{mg}$ $\mathrm{kg}^{-1}$ ), arsenic (3818 $\mathrm{mg} \mathrm{kg}^{-1}$ ) and cadmium (21 
Table 2

Total and available (EDTA) concentrations of $S$ and trace elements in the affected and unaffected soils (mean \pm S.E. of three samples)

\begin{tabular}{|c|c|c|c|c|c|c|c|c|c|}
\hline Depth $(\mathrm{cm})$ & Fraction & Soil & $\mathrm{S}(\%)$ & $\mathrm{Mn}\left(\mathrm{mg} \mathrm{kg}^{-1}\right)$ & $\mathrm{Cu}\left(\mathrm{mg} \mathrm{kg}^{-1}\right)$ & $\mathrm{Zn}\left(\mathrm{mg} \mathrm{kg}^{-1}\right)$ & As $\left(\mathrm{mg} \mathrm{kg}^{-1}\right)$ & $\mathrm{Cd}\left(\mathrm{mg} \mathrm{kg}^{-1}\right)$ & $\mathrm{Pb}\left(\mathrm{mg} \mathrm{kg}^{-1}\right)$ \\
\hline \multirow[t]{3}{*}{$0-25$} & Total & Affected & $0.46 \pm 0.04^{*}$ & $430 \pm 19^{*}$ & $40.3 \pm 1.9^{*}$ & $209 \pm 18^{*}$ & $65.6 \pm 6.3^{*}$ & - & $113 \pm 11^{*}$ \\
\hline & & Unaffected & $0.02 \pm 0.002$ & $511 \pm 19$ & $15.9 \pm 0.4$ & $60.6 \pm 0.8$ & $10.4 \pm 0.8$ & - & $29.5 \pm 4.3$ \\
\hline & EDTA & Affected & - & $23.9 \pm 0.9^{*}$ & $7.94 \pm 0.32^{*}$ & $39.5 \pm 5.1^{*}$ & $0.31 \pm 0.01^{*}$ & $0.24 \pm 0.03^{*}$ & $19.7 \pm 1.8^{*}$ \\
\hline \multirow[t]{3}{*}{$25-40$} & Total & Affected & $0.16 \pm 0.05^{*}$ & $426 \pm 32$ & $22.3 \pm 3.8$ & $99.5 \pm 23.4$ & $24.1 \pm 7.9$ & - & $42.3 \pm 12.8$ \\
\hline & & Unaffected & $0.02 \pm 0.001$ & $501 \pm 15$ & $15.0 \pm 0.01$ & $61.3 \pm 1.3$ & $11.4 \pm 1.3$ & - & $32.4 \pm 6.1$ \\
\hline & EDTA & Affected & - & $23.0 \pm 1.8$ & $4.07 \pm 0.61$ & $13.5 \pm 5.6$ & $0.01 \pm 0.001$ & $0.09 \pm 0.03$ & $7.9 \pm 2.1$ \\
\hline $\begin{array}{l}\text { Toxic for } \\
\text { plants }^{\mathrm{b}}\end{array}$ & Range & & - & $1500-3000$ & $60-125$ & 70-400 & $15-50$ & $3-8$ & $100-400$ \\
\hline
\end{tabular}

a Bowen (1979).

${ }^{\mathrm{b}}$ Kabata-Pendias and Pendias (1992)

${ }^{*}$ Significant differences from the unaffected soil $(P<0.05$ of Student's $t$-test $)$ are marked with asterisks. 
Table 3

Height, above-ground and root mass, 1000 seeds weight and seed and oil production per plant (mean \pm S.E. of three samples for V4 and nine samples for R8, dry matter) of sunflower plants growing in the spill-affected and unaffected soils

\begin{tabular}{llllllll}
\hline Crop stage & Soil & $\begin{array}{l}\text { Height } \\
(\mathrm{cm})\end{array}$ & $\begin{array}{l}\text { Above-ground mass } \\
(\mathrm{g})\end{array}$ & $\begin{array}{l}\text { Root mass } \\
(\mathrm{g})\end{array}$ & $\begin{array}{l}\text { Seed weight } \\
(\mathrm{mg})\end{array}$ & $\begin{array}{l}\text { Seed production } \\
(\mathrm{g})\end{array}$ & $\begin{array}{l}\text { Oil production } \\
(\%)\end{array}$ \\
\hline V4 & Affected & - & $0.74 \pm 0.04^{*}$ & $0.08 \pm 0.004^{*}$ & - & - & - \\
& Unaffected & - & $1.07 \pm 0.10$ & $0.13 \pm 0.01$ & - & - & - \\
$\mathrm{R} 8$ & Affected & $131 \pm 3$ & $390 \pm 29$ & $27.0 \pm 0.9$ & $96.5 \pm 4.1$ & $102 \pm 4$ & $35.1 \pm 0.7^{*}$ \\
& Unaffected & $136 \pm 3$ & $404 \pm 35$ & $28.8 \pm 1.6$ & $88.0 \pm 3.4$ & $98.6 \pm 3.5$ & $32.9 \pm 0.6$ \\
\hline
\end{tabular}

* Significant differences from the unaffected soil $(P<0.05$ of Student's $t$-test $)$ are marked with asterisks.

$\mathrm{mg} \mathrm{kg}^{-1}$ ) (values for the sludge layer in the same study area from Murillo et al., 1999). Consequently, the values for available (EDTA-extracted) $\mathrm{Pb}$, As and $\mathrm{Cd}$ in the spill-affected topsoil were higher $(2 \times, 14 \times$ and $8 \times$, respectively), than in the nonaffected experimental plot (Table 2). Comparison with the soil pollution in the early period after the main spill shows that the pattern of pollution (increase in relation to the unaffected soil) by available $\mathrm{Pb}$ and $\mathrm{Cd}$ had not changed significantly. Even worse, the pollution derived from available As had increased in 2000 (2nd scenario).

Soil pollution in the experimental plot located in the spill-affected area is still high for $\mathrm{Zn}$, As, $\mathrm{Cd}, \mathrm{Pb}$ and $\mathrm{Cu}$, despite the clean-up and remediation operations of the last 2 years. Soil pollution could have been much worse if the thick sludge layer had not been removed a few months after the accident, in a complex and expensive operation (see Cabrera et al., 2003 for a general view of the soil pollution in the Guadiamar valley). However, at some sites the cleaning machinery buried part of the sludge, previously confined to the topsoil, and increased the concentration of metals in the arable layer of the soil (Madejón et al., 2002).

\subsection{Plant growth and performance}

Soil pollution significantly retarded early growth of sunflower, but the final harvest was not significantly affected (Table 3). The above-ground biomass and root mass of seedlings (stage V4) were significantly smaller in the spill-affected soil. Roots of the affected plants were 1.6-fold smaller, and shoots 1.4-fold smaller. In general, toxic metal ions primarily restrict root growth (Rengel, 1997), thereby impairing nutrient uptake and reducing shoot growth.

Mature plants (R8 stage) reached a similar height and above-ground and root mass in both soil conditions (Table 3). Apparently, sunflower plants were able to overcome physiological constraints imposed by soil pollution during early growth. Moreover, yield components were somewhat greater in plants grown in spill-affected soil; in particular, the oil production was significantly higher than at the non-affected site (Table 3). This favourable result supports the potential use of sunflower for phytoremediation, providing the added value of biomass and oil (see an overview of phytoremediation perspectives in Van der Lelie et al., 2001).

The sunflower plants flooded by the spill in 1998 also produced slightly higher seed mass than nearby plants in non-affected soils: mean of 136 $\mathrm{g} /$ plant vs. $127 \mathrm{~g} /$ plant (Murillo et al., 1999). These results, in both the 1st and 2nd scenarios, support the ability of sunflower to tolerate soil pollution and to produce seeds under adverse conditions.

\subsection{Plant chemical composition}

Although the plant mass was not significantly affected by soil pollution, the chemical composition of the plant organs in sunflowers grown in spill-affected soil differed significantly from that in those at the non-affected site (Tables 4 and 5). We now discuss the main effects of soil pollution on the chemical composition of sunflower plants, separating three groups of elements: (1) macronutrients $(\mathrm{N}, \mathrm{P}, \mathrm{K}, \mathrm{S}, \mathrm{Ca}$ and $\mathrm{Mg}$ ); (2) micronu- 
Table 4

Micronutrients and trace elements concentrations (mean \pm S.E. of three samples, dry matter) in different fractions of sunflower seedlings (stage V4) growing in the affected and unaffected soils

\begin{tabular}{|c|c|c|c|c|c|c|c|c|c|}
\hline Fraction & Soil & $\mathrm{Cu}\left(\mathrm{mg} \mathrm{kg}^{-1}\right)$ & $\mathrm{Fe}\left(\mathrm{mg} \mathrm{kg}^{-1}\right)$ & $\mathrm{Mn}\left(\mathrm{mg} \mathrm{kg}^{-1}\right)$ & $\mathrm{Zn}\left(\mathrm{mg} \mathrm{kg}^{-1}\right)$ & As $\left(\mu \mathrm{g} \mathrm{kg}^{-1}\right)$ & $\mathrm{Cd}\left(\mu \mathrm{g} \mathrm{kg}^{-1}\right)$ & $\mathrm{Pb}\left(\mu \mathrm{g} \mathrm{kg}^{-1}\right)$ & $\mathrm{Tl}\left(\mu \mathrm{g} \mathrm{kg}^{-1}\right)$ \\
\hline \multirow[t]{2}{*}{ Expanded leaves } & Affected & $22.9 \pm 1.7 *$ & $77.4 \pm 6.1$ & $44.1 \pm 1.2^{*}$ & $98.0 \pm 1.8^{*}$ & $20.6 \pm 7.4$ & $500 \pm 31^{*}$ & $634 \pm 15^{*}$ & $88.9 \pm 5.9 *$ \\
\hline & Unaffected & $11.2 \pm 0.9$ & $88.0 \pm 3.2$ & $90.7 \pm 6.5$ & $24.3 \pm 1.2$ & $13.9 \pm 12.7$ & $152 \pm 15$ & $363 \pm 23$ & $37.2 \pm 8.9$ \\
\hline \multirow[t]{2}{*}{ Stems } & Affected & $15.7 \pm 0.9^{*}$ & $39.3 \pm 2.3$ & $23.4 \pm 0.3^{*}$ & $152 \pm 7.6^{*}$ & $61.8 \pm 18.1^{*}$ & $414 \pm 28^{*}$ & $1439 \pm 148^{*}$ & $148 \pm 14^{*}$ \\
\hline & Unaffected & $8.5 \pm 0.6$ & $36.6 \pm 1.0$ & $36.4 \pm 2.7$ & $33.4 \pm 1.4$ & $11.3 \pm 0.9$ & $120 \pm 25$ & $458 \pm 66$ & $12.1 \pm 1.4$ \\
\hline \multirow[t]{2}{*}{ Roots } & Affected & $11.5 \pm 0.09^{*}$ & $300 \pm 44$ & $10.9 \pm 0.5^{*}$ & $57.8 \pm 3.1^{*}$ & $2057 \pm 191^{*}$ & $281 \pm 36^{*}$ & $5210 \pm 571^{*}$ & $215 \pm 13^{*}$ \\
\hline & Unaffected & $9.6 \pm 0.3$ & $433 \pm 95$ & $26.5 \pm 2.2$ & $29.2 \pm 0.1$ & $304 \pm 63$ & $110 \pm 9.8$ & $1421 \pm 253$ & $18.2 \pm 1.6$ \\
\hline
\end{tabular}

Asterisk means significant difference $(P<0.05)$ according to Student's $t$-test. 
Table 5

Micronutrients and trace element concentrations (mean \pm S.E. of nine samples, dry matter) in different fractions of mature plants of sunflower plants (stage R8) growing in the affected and unaffected soils ${ }^{\mathrm{a}}$

\begin{tabular}{|c|c|c|c|c|c|c|c|c|c|}
\hline Fraction & Soil & $\mathrm{Cu}\left(\mathrm{mg} \mathrm{kg}^{-1}\right)$ & $\mathrm{Fe}\left(\mathrm{mg} \mathrm{kg}^{-1}\right)$ & $\operatorname{Mn}\left(\mathrm{mg} \mathrm{kg}^{-1}\right)$ & $\mathrm{Zn}\left(\mathrm{mg} \mathrm{kg}^{-1}\right)$ & As $\left(\mu \mathrm{g} \mathrm{kg}^{-1}\right)$ & $\mathrm{Cd}\left(\mu \mathrm{g} \mathrm{kg}^{-1}\right)$ & $\mathrm{Pb}\left(\mu \mathrm{g} \mathrm{kg}^{-1}\right)$ & $\mathrm{Tl}\left(\mu \mathrm{g} \mathrm{kg}^{-1}\right)$ \\
\hline \multirow[t]{2}{*}{ Seeds } & Affected & $23.4 \pm 0.5$ & $59.8 \pm 1.8 *$ & $20.2 \pm 0.6^{*}$ & $112 \pm 4.3 *$ & $17.3 \pm 4.5$ & $239 \pm 17 *$ & $219 \pm 16$ & $9.33 \pm 0.89 *$ \\
\hline & Unaffected & $21.9 \pm 0.7$ & $66.4 \pm 1.7$ & $23.9 \pm 0.9$ & $73.1 \pm 3.7$ & $12.2 \pm 2.4$ & $130 \pm 10$ & $167 \pm 28$ & $4.77 \pm 0.45$ \\
\hline \multirow[t]{2}{*}{ Head } & Affected & $23.0 \pm 1.1 *$ & $30.6 \pm 2.2$ & $8.11 \pm 0.52$ & $51.1 \pm 2.5^{*}$ & $100 \pm 11$ & $170 \pm 32 *$ & $472 \pm 105$ & $48.0 \pm 5.8 *$ \\
\hline & Unaffected & $20.0 \pm 1.0$ & $37.4 \pm 3.9$ & $8.44 \pm 0.64$ & $34.8 \pm 5.3$ & $82.4 \pm 6.7$ & $50.2 \pm 3.6$ & $477 \pm 120$ & $26.1 \pm 3.3$ \\
\hline \multirow[t]{2}{*}{ Blades } & Affected & $24.5 \pm 2.5^{*}$ & $90.5 \pm 3.2$ & $51.0 \pm 1.7 *$ & $68.5 \pm 7.3^{*}$ & $488 \pm 15^{*}$ & $250 \pm 26^{*}$ & $1985 \pm 116^{*}$ & $94.8 \pm 13.0 *$ \\
\hline & Unaffected & $13.9 \pm 1.4$ & $96.5 \pm 4.1$ & $87.0 \pm 3.0$ & $16.4 \pm 0.6$ & $331 \pm 33$ & $88.7 \pm 4.5$ & $1335 \pm 42.8$ & $52.2 \pm 10.3$ \\
\hline \multirow[t]{2}{*}{ Petioles } & Affected & $4.82 \pm 0.45$ & $26.7 \pm 3.7$ & $29.8 \pm 2.2 *$ & $75.8 \pm 9.8 *$ & $150 \pm 8.4$ & $227 \pm 33^{*}$ & $823 \pm 39$ & $89.9 \pm 11.3 *$ \\
\hline & Unaffected & $3.67 \pm 0.79$ & $22.1 \pm 1.7$ & $48.0 \pm 2.3$ & $21.5 \pm 12$ & $149 \pm 15.4$ & $93.3 \pm 52$ & $754 \pm 92$ & $39.8 \pm 19.4$ \\
\hline \multirow[t]{2}{*}{ Stems } & Affected & $11.8 \pm 1.2^{*}$ & $11.3 \pm 1.9 *$ & $12.1 \pm 0.3^{*}$ & $75.3 \pm 5.7 *$ & $123 \pm 9.5$ & $123 \pm 18 *$ & $777 \pm 35^{*}$ & $84.3 \pm 9.0 *$ \\
\hline & Unaffected & $7.21 \pm 0.8$ & $20.3 \pm 2.0$ & $17.7 \pm 0.8$ & $11.7 \pm 0.4$ & $149 \pm 10.8$ & $70.9 \pm 8.1$ & $525 \pm 30$ & $21.4 \pm 1.4$ \\
\hline \multirow[t]{2}{*}{ Roots } & Affected & $15.9 \pm 1.3^{*}$ & $816 \pm 50.2$ & $11.2 \pm 1.2^{*}$ & $52.0 \pm 7.7 *$ & $4859 \pm 618^{*}$ & $454 \pm 51 *$ & $9132 \pm 1393 *$ & $325 \pm 54^{*}$ \\
\hline & Unaffected & $7.42 \pm 1.2$ & $893 \pm 57.5$ & $20.4 \pm 1.6$ & $21.4 \pm 2.8$ & $1437 \pm 515$ & $160 \pm 30$ & $3198 \pm 677$ & $58.6 \pm 23.4$ \\
\hline
\end{tabular}

a Asterisk means significant difference $(P<0.05)$ according to Student's $t$-test. 

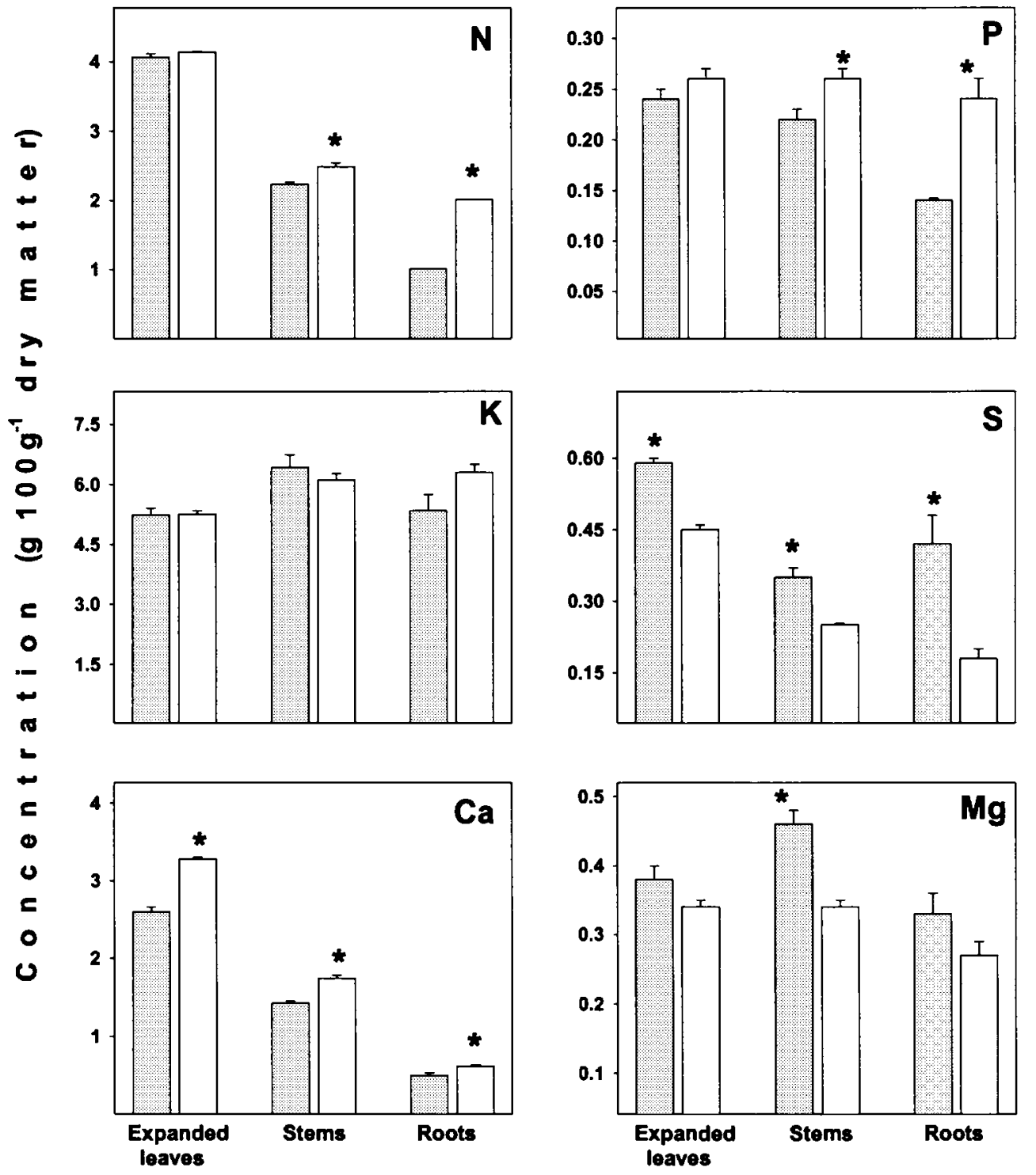

Plant fractions (growth stage: V4)

Fig. 1. Nutrient concentrations (mean values on dry matter and S.E. bars) in sunflower growing at V4 stage on the affected (gray) and non-affected (white) soils. For each fraction, significant differences are marked with asterisks $(P<0.05$ of Student's $t$-test).

trients $(\mathrm{Fe}, \mathrm{Mn}, \mathrm{Zn}$ and $\mathrm{Cu})$; and (3) trace elements ( $\mathrm{As}, \mathrm{Cd}, \mathrm{Pb}$ and $\mathrm{Tl})$.

\subsubsection{Macronutrients}

The concentration of $\mathrm{N}$ in stems and roots (but not in leaves) of seedlings (V4 stage) was signif- icantly lower at the spill-affected site (Fig. 1). The sunflower has a high $\mathrm{N}$ requirement, and consequently $\mathrm{N}$ deficiency is the most important nutritional limitation to this crop production (Blamey et al., 1997). The total $\mathrm{N}$ content of seedlings growing at the spill-affected site $(26 \mathrm{mg} \mathrm{N} /$ 
seedling) was lower than at the non-affected site (41 mg N/seedling), due to their reduced growth at that stage.

Soil pollution caused a reduced root growth at early stages and, in consequence, a lower $\mathrm{N}$ uptake. At more advanced stages, $\mathrm{N}$ uptake seemed to be less limiting. The root system mass reached at stage R8 was similar for plants in polluted and non-affected soils (Table 3); probably they were able to explore deeper horizons in the soil, which were less polluted (Table 2).

The $\mathrm{N}$ concentrations in leaf blades and roots in mature plants (R8 stage) grown in polluted soils were not significantly different from those at the non-affected site (Fig. 2). However, the structural (stem and petiole) and reproductive (head and seed) organs did have a lower $\mathrm{N}$ concentration in the polluted plants (Fig. 2). The total (mean) value of $\mathrm{N}$ accumulated in the plant mass in the polluted soil was $6.79 \mathrm{~g}$, compared with $8.05 \mathrm{~g}$ in the non-affected soil (non-significantly different by $t$-test); and total $\mathrm{N}$ content in seeds was 3.64 $\mathrm{g} /$ plant in polluted soil compared with a similar $3.84 \mathrm{~g} /$ plant in the non-polluted soil.

Nitrogen concentration in seeds was relatively high (greater than $3.5 \mathrm{~g} \mathrm{~N} 100 \mathrm{~g} \mathrm{~g}^{-1}$ dry matter) in the polluted soil, and seems to indicate adequate $\mathrm{N}$ nutrition, once the seedling stage is left behind. Blamey et al. (1997) reported a range of 2.58-3 g N $100 \mathrm{~g}^{-1}$ dry matter for sunflower seeds.

Phosphorus deficiency is probably the second (after N) major nutrient limitation to sunflower production. At the Guadiamar spill-affected site, $\mathrm{P}$ acquisition by sunflower plants was impaired. Polluted seedlings (V4 stage) had lower P concentration in roots and stems (but not in leaves) than did non-polluted ones (Fig. 1) - a trend similar to the $\mathrm{N}$ accumulation pattern. Polluted mature plants (R8 stage) had consistently lower P concentration in every organ compared with non-polluted plants (Fig. 2). Leaf blades and petioles were particularly deprived of $P$ (approx. three-fold lower), compared with non-polluted plants. The $\mathrm{P}$ uptake in the whole plant was $1.01 \mathrm{~g}$ in the polluted soil, significantly lower than at the non-affected site (mean of $1.57 \mathrm{~g} \mathrm{P} /$ plant).

Sunflower seeds in the polluted soil had $0.54 \mathrm{~g}$ $\mathrm{P} / 100 \mathrm{~g}$ dry matter. This value was significantly lower than in the non-polluted soil (mean of 0.67 $\mathrm{g} \mathrm{P} / 100 \mathrm{~g}$ dry matter); however, it is within the range of $\mathrm{P}$ concentration for normal sunflower crop (approx. 0.4\%), and well above the critical concentration $(0.2 \%)$ indicating $\mathrm{P}$ deficiency (Reuter and Robinson, 1997). Total P accumulation in seeds of polluted plants was $0.55 \mathrm{~g} / \mathrm{plant}$, significantly lower than at the non-polluted site (mean of $0.66 \mathrm{~g} \mathrm{P} /$ plant).

Comparing the 1st (1998) and 2nd (2000) scenarios, we observe a reverse pattern. Seeds of the spill-flooded plants had higher concentrations of $\mathrm{N}$ and $\mathrm{P}$ than those of non-polluted plants (Murillo et al., 1999), whereas plants grown in polluted and remediated soils 2 years later had lower $\mathrm{N}$ and $\mathrm{P}$ in their seeds than did non-polluted plants (as shown above, Fig. 2). Murillo et al. (1999) interpreted the increased $\mathrm{N}$ and $\mathrm{P}$ acquisition by the spill-affected plants as an indirect result of soil moistening and acidification, derived from the large amount of acid water supplied by the spill (fertilising effect); 2 years later, plants have grown in the remediated soil under rainfed conditions, without supplemental watering.

The influence of the sludge pollution on potassium nutrition was not very pronounced, at either the seedling (V4, Fig. 1) or the mature (R8, Fig. 2 ) stages. The high concentration of $K$ in every plant organ at the seedling (V4) and mature (R8) stages, in both soil conditions, may be an effect of 'luxury' consumption of this element. Plants tend to uptake and accumulate an excess of $\mathrm{K}$ when it is abundant in the soil (see overview in Marschner, 1995, and reports for sunflower in Mathers and Stewart, 1982). Acetate-extractable K in the soil of both plots $(0-25 \mathrm{~cm})$ was approximately $300 \mathrm{mg} \mathrm{kg}^{-1}$ after fertilisation with the NPK complex fertiliser, a very high value according to most data in the literature (Haby et al., 1990).

The concentration of sulfur was significantly higher in every organ of the polluted seedlings (Fig. 1), and of the polluted mature plants (with the exception of seeds, Fig. 2), compared with plants in non-polluted soil. This high accumulation of $\mathrm{S}$ in polluted plants is a reflection of the high $\mathrm{S}$ concentration in the spill-affected soil (Table 2). The differences in $\mathrm{S}$ concentration between pollut- 


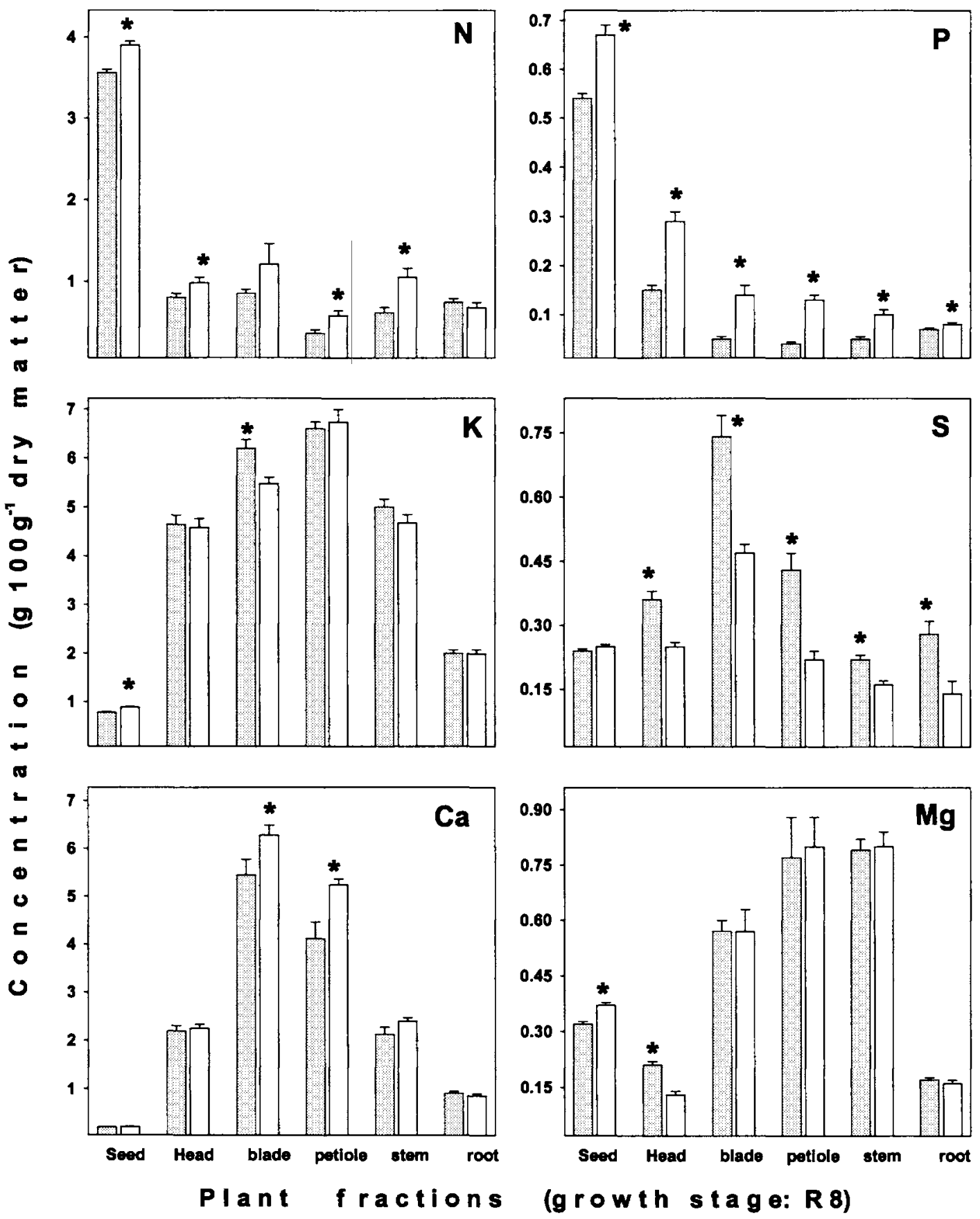

Fig. 2. Nutrient concentrations (mean values on dry matter and S.E. bars) in sunflower growing at R8 stage on the affected (gray) and non-affected (white) soils. For each fraction, significant differences are marked with asterisks $(P<0.05$ of Student's $t$-test). 
ed and non-polluted plants were especially marked for the roots (at V4 and R8 stages) and leaves (at R8 stage). In general, plants are rather insensitive to high sulfate concentration in the soil medium (except in the case of saline soils); when the sulfate taken up exceeds the $\mathrm{S}$ demand for the synthesis of organic compounds, it can be stored in plant tissues without much damage (Marschner, 1995).

The application of $\mathrm{S}$ fertilisers to sunflower crops increases yield and oil concentration (Sing and Sahu, 1986; Blamey et al., 1997). The high S content of the spill-affected soil could have induced, at least partly, the significantly greater oil concentration in seeds of polluted vs. non-polluted plants (Table 3). This higher production of sunflower oil in polluted soils, probably due to the $S$ enrichment, can be considered as added value in planning the utilisation of this plant in phytoremediation.

The pattern of $\mathrm{Ca}$ and $\mathrm{Mg}$ concentration changed with plant age. At the seedling (V4) stage, they showed opposite trends (Fig. 1), probably associated with the well-known antagonism effect produced during the plant's uptake of these two elements. At maturity (R8 stage), leaf blades and petioles showed a pollution-induced $\mathrm{Ca}$ depletion, whereas other plant organs accumulated $\mathrm{Ca}$ levels similar to those in non-polluted plants (Fig. 2). The concentration of $\mathrm{Mg}$ was not very different between the two soil conditions for the vegetative organs. Concentrations of $\mathrm{Ca}$ and $\mathrm{Mg}$ in the seeds of polluted plants ( 0.19 and $0.32 \%$, respectively), were normal for sunflower crop (Blamey et al., 1997). Overall, Ca uptake was greater in the unaffected plants (12.7 $\mathrm{g}$ per plant) than in the affected plants (10.6 g per plant), but similar in the case of $\mathrm{Mg}$ (1.87 $\mathrm{g}$ per plant in both groups of plants).

Comparing the 1st (1998) and 2nd (2000) scenarios, Ca concentration in seeds was not affected in either year studied. However, $\mathrm{Ca}$ in leaves was higher in the flood-affected plants (compared with non-polluted plants) in 1998 and lower in the 2000 plants grown on remediated soils (Murillo et al., 1999). The higher Ca accumulation in plants subjected to the spill flood could be a consequence of carbonate dissolution following the soil acidification produced by the irruption of sludge and acid water. The concentration of $\mathrm{Mg}$ in seeds was not affected by sludge pollution in the 1st scenario (a pattern similar to that of $\mathrm{Ca}$ ), but it was lower in the polluted plants of the 2nd scenario (as shown above). In general, the supply of $\mathrm{Ca}$ and $\mathrm{Mg}$ was adequate in both scenarios, as a normal feature in alkaline soils.

\subsubsection{Micronutrients}

Although essential for plant growth, micronutrients $(\mathrm{Fe}, \mathrm{Mn}, \mathrm{Zn}$ and $\mathrm{Cu})$ can produce toxic effects if they reach very high concentration in the plant tissues. Concentrations of $\mathrm{Fe}$ in polluted seedlings were not significantly different from those in non-polluted ones (Table 4). However, seeds and stems of polluted mature plants had lower $\mathrm{Fe}$ concentration than those of non-polluted plants (Table 5). Total uptake of $\mathrm{Fe}$ by mature plants was also lower in polluted soil conditions (Fig. 3). Despite this reduced Fe accumulation in polluted plants, the Fe concentration in their seeds (mean of $59.8 \mathrm{mg} \mathrm{kg}^{-1}$ ) was higher than the normal value $\left(33 \mathrm{mg} \mathrm{kg}^{-1}\right)$ reported for sunflower crop (Blamey et al., 1997).

The mine sludge originating the soil pollution had a high concentration of Fe (approx. 370000 $\mathrm{mg} \mathrm{kg}{ }^{-1}$ ), but spill-affected soils did not present significantly increased $\mathrm{Fe}$ content (López-Pamo et al., 1999). In fact, Fe (EDTA-extracted) availability of the polluted and remediated soil used to grow sunflower in this study $\left(40 \mathrm{mg} \mathrm{kg}^{-1}\right.$ in $0-$ $25-\mathrm{cm}$ depth) was not significantly different from that of the non-polluted soil used for comparison $\left(45 \mathrm{mg} \mathrm{kg}^{-1}\right)$. Therefore, sunflower plants grown in spill-polluted soil did not show symptoms of Fe toxicity.

The concentration of $\mathrm{Mn}$ in seedlings and mature plants was much lower in the polluted soil (Tables 4 and 5) than at the non-polluted site. This apparent reduction of $\mathrm{Mn}$ accumulation was found in every plant organ, with the exception of flower heads (Table 5). Total uptake of Mn by the mature plant was thus much reduced in the polluted soil (Fig. 3). The apparently contradictory pattern of reduced $\mathrm{Mn}$ accumulation in polluted plants is a reflection of the significantly lower 


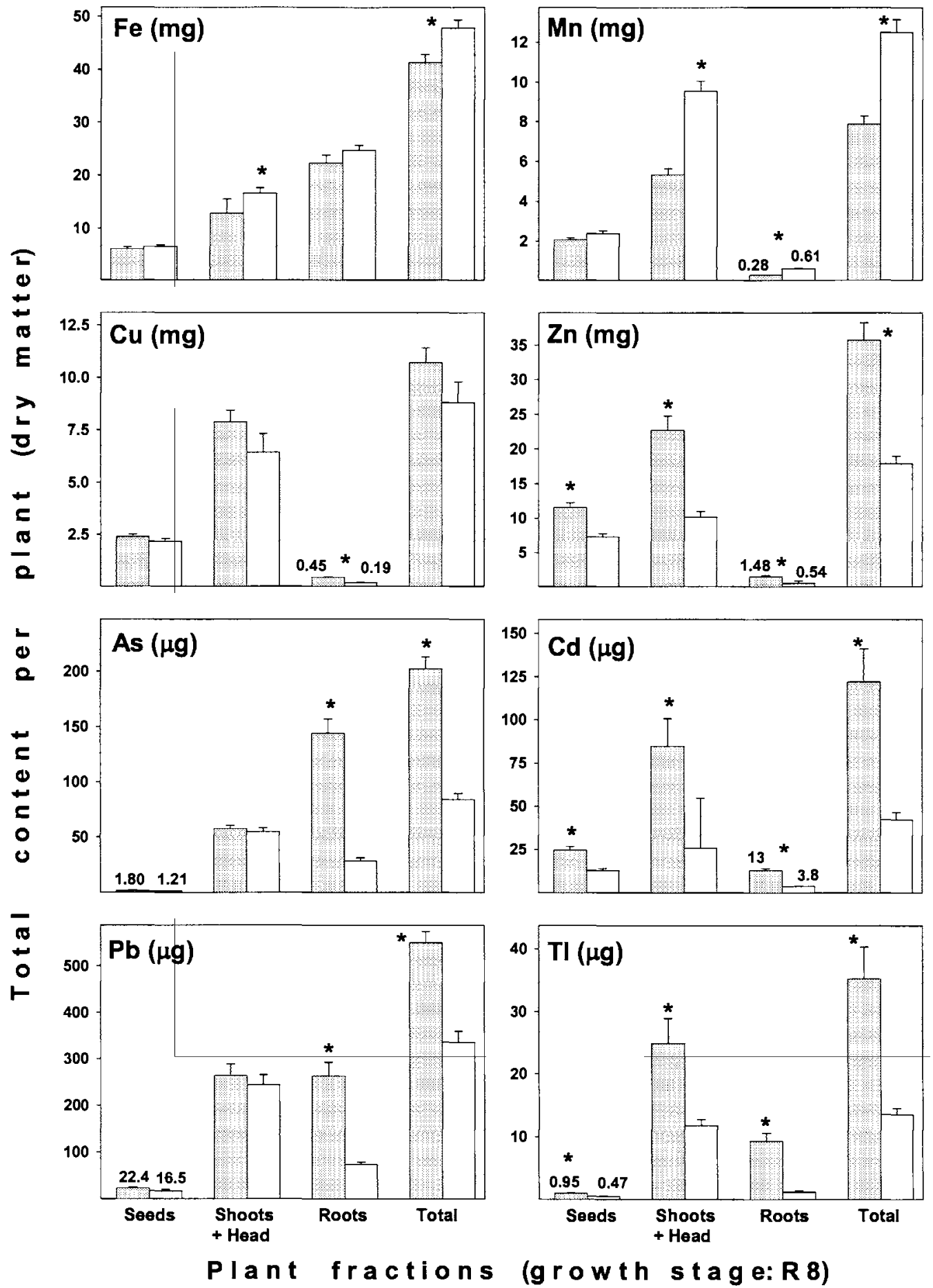

Fig. 3. Total content per plant of micronutrients and trace elements (mean values on dry matter and S.E. bars) in different fractions of sunflower growing at R8 stage on the affected (gray) and non-affected (white) soils. For each fraction, significant differences are marked with asterisks $(P<0.05$ of Student's $t$-test $)$. 
availability of this heavy metal in the polluted soil (Table 2) than at the non-polluted site.

Despite the (relatively) low Mn concentration in polluted plants, their seeds had a high $\mathrm{Mn}$ content: mean of $20 \mathrm{mg} \mathrm{kg}^{-1}$, compared with the $14 \mathrm{mg} \mathrm{kg}^{-1}$ reported for normal sunflower crops (Blamey et al., 1997). The concentration of $\mathrm{Mn}$ in the sludge was relatively low (lower than the median for normal soils, according to Bowen, 1979), and the high accumulation of Mn found in plants, both polluted and non-polluted, must be a reflection of an inherent high Mn availability in the background soil of the region.

Concentrations of the micronutrients $\mathrm{Cu}$ and $\mathrm{Zn}$ (in contrast to $\mathrm{Fe}$ and $\mathrm{Mn}$ ) in seedlings and mature plants were higher in those in the polluted soil than in those at the non-polluted site (Tables 4 and 5). The increased accumulation of heavy metal in plants, induced by soil pollution, was more pronounced in the case of $\mathrm{Zn}$, one of the major polluting elements in the mine sludge (Cabrera et al., 1999).

The concentration of $\mathrm{Cu}$ was significantly higher in every seedling organ (V4 stage, Table 4) and in most of the mature plant organs (with the exception of seeds and leaf petioles, Table 5) in the polluted soil than in those at the non-polluted site. However, total plant uptake of $\mathrm{Cu}$ was not significantly different between the two soil conditions (Fig. 3). Only root uptake of $\mathrm{Cu}$ showed a significant increase under polluted soil conditions (Fig. 3).

Copper reached its highest concentration in the leaf blades of mature plants, with a mean value of $24.5 \mathrm{mg} \mathrm{kg}$. . The maximum value of $36 \mathrm{mg}$ $\mathrm{kg}^{-1}$ would be already within the phytotoxic range for most plants: $25-40 \mathrm{mg} \mathrm{kg}{ }^{-1}$, according to Chaney (1989), although a higher threshold of 70 $\mathrm{mg} \mathrm{kg}^{-1}$ has been reported for sunflower (Blamey et al., 1997).

Sunflower plants directly flooded by the spill in 1998 (1st scenario) did show a significantly greater $\mathrm{Cu}$ accumulation in their seeds (mean of 27.2 $\mathrm{mg} \mathrm{kg}^{-1}$ ) than those in adjacent non-polluted soils (Murillo et al., 1999). On the other hand, there is a decreasing trend of $\mathrm{Cu}$ accumulation in the polluted plants between the 1st (1998) and 2nd
(2000) scenarios, e.g. leaf blades decreased from a mean value of $63.0 \mathrm{mg} \mathrm{kg}^{-1}$ of $\mathrm{Cu}$ in the spillflood conditions (1998) to a mean of $24.5 \mathrm{mg}$ $\mathrm{kg}^{-1}$ in the remediated soils (2000). In general, contamination by $\mathrm{Cu}$ in plants was quite low in comparison to that by other toxic elements, such as $\mathrm{As}, \mathrm{Cd}, \mathrm{Pb}$ and $\mathrm{Zn}$. The temporal reduction of $\mathrm{Cu}$ accumulation in plants of the spill-affected area has also been documented for wild grasses (Madejón et al., 2002) and white poplar, wild olive and holm oak (Madejón et al., unpublished).

The concentration of $\mathrm{Zn}$ in plants growing in the polluted soil was significantly higher for every organ, at both seedling and mature plant stages (Tables 4 and 5), compared with those in nonpolluted soil. Total $\mathrm{Zn}$ uptake, for the entire plant and for the fractions analysed, was also significantly greater in the polluted soil than in nonpolluted soil (Fig. 3). Despite this clear effect of increasing $\mathrm{Zn}$ accumulation induced by the soil pollution, the values reached (maximum of 163 $\mathrm{mg} \mathrm{kg}^{-1}$ in one seedling stem) were always below the phytotoxic levels for plants [500-1500 mg $\mathrm{kg}^{-1}$, according to Chaney (1989)]. Seeds (the edible part in this crop) of polluted plants had a $\mathrm{Zn}$ concentration (mean of $112 \mathrm{mg} \mathrm{kg}^{-1}$ ) below the maximum level tolerated by animals, (e.g. $1000 \mathrm{mg} \mathrm{kg}^{-1}$ for chicken, according to Chaney 1989).

Plants directly affected by the spill in 1998 (1st scenario) showed higher $\mathrm{Zn}$ concentration than those cultivated in adjacent, non-affected soils (Murillo et al., 1999). However, there is a trend of decreasing $\mathrm{Zn}$ accumulation in plants with time. Leaf blades of spill-flooded plants (in the 1st scenario, 1998) had a mean of $140 \mathrm{mg} \mathrm{kg}^{-1}$ of $\mathrm{Zn}$, whereas plants grown in remediated soils ( $2 \mathrm{nd}$ scenario, in 2000) had a mean $\mathrm{Zn}$ concentration of $68.5 \mathrm{mg} \mathrm{kg}^{-1}$. This reduction in $\mathrm{Zn}$ accumulation with time was also found for leaf petioles and stems, however, seeds harvested in the 2nd scenario had more $\mathrm{Zn}$ (mean of $112 \mathrm{mg} \mathrm{kg}^{-1}$ ) than those in the 1st scenario (mean of $73.6 \mathrm{mg} \mathrm{kg}^{-1}$ ).

Soil pollution by the mine spill did significantly affect sunflower plants, in terms of higher $\mathrm{Zn}$ accumulation in their tissues. Two years after the spill, remediated soils are still contaminated by 
$\mathrm{Zn}$, and consequently affect plants, inducing a higher $\mathrm{Zn}$ accumulation in their tissues. However, there is evidence that $\mathrm{Zn}$ accumulation in plants is decreasing, as shown for sunflower plants (in this study, and despite the contradictory values for seeds), and wild grasses (Madejón et al., 2002).

\subsubsection{Trace elements}

The trace elements $\mathrm{As}, \mathrm{Cd}, \mathrm{Pb}$ and $\mathrm{Tl}$ are not essential for plant nutrition, and can have phytotoxic effects, even at low concentration. These four elements were present in the mine spill flooding the Guadiamar valley and, as a result, polluted sunflower plants had higher concentration of $\mathrm{As}, \mathrm{Cd}, \mathrm{Pb}$ and $\mathrm{Tl}$ in their organs than did nonpolluted plants (Table 4 and Table 5, Fig. 3).

Arsenic was one of the trace elements causing public concern after the mine spill, due to its known toxicity. Plant uptake of As occurs primarily through the root system, and the highest As concentration is usually reported in root and tuber tissues; its accumulation in other (edible) parts is generally low (Smith et al., 1998). Polluted sunflower plants (in this study) accumulated As mainly in the roots, at both seedling (V4) and adult (R8) stages (Table 4 and Table 5). For example, the transfer coefficient for roots was 0.08 and for leaves was $6 \times 10^{-4}$, for mature plants in the polluted soil. The maximum value reached (7.9 $\mathrm{mg} \mathrm{kg} \mathrm{kg}^{-1}$ in roots of one mature plant) is within the range of 3-10 $\mathrm{mg} \mathrm{kg}^{-1}$ for phytotoxic effects (Chaney, 1989). Given that most of the As was accumulated in roots, and thus stayed below ground, at soil level, the potential for phytoextraction and removal of As by harvesting aboveground sunflower organs, seems to be very low.

Sunflower seeds (the edible part) accumulated much lower concentrations of As than did roots or leaves (Table 5 and Fig. 3), and the measured values in polluted plants (mean of $17.3 \mu \mathrm{g} \mathrm{kg}^{-1}$ ) were not significantly different to those in nonpolluted conditions. These As values are far below the accepted toxicity thresholds, e.g. 3000-10 000 $\mu \mathrm{g} \mathrm{kg}^{-1}$ for phytoxicity effects (Chaney, 1989), approximately $50000 \mu \mathrm{g} \mathrm{kg}^{-1}$ in dry diet for animal consumption (Blamey et al., 1997) and
$1000 \mu \mathrm{g} \mathrm{kg}^{-1}$ in dry diet as health limit for humans (Smith et al., 1998).

During the 1st scenario (1998), spill-flooded sunflower plants also had comparatively low As concentration in seeds (mean of $31 \mu \mathrm{g} \mathrm{kg}{ }^{-1}$, Murillo et al., 1999). The physiological barrier for translocation of trace elements to seeds acted effectively in sunflower plants cultivated in polluted and remediated soils (2000, 2nd scenario), as well as in plants directly suffering the spill flood (1998, 1st scenario). Leaves of spill-flooded sunflower (1st scenario) had a very high As concentration (mean of $5815 \mu \mathrm{g} \mathrm{kg}^{-1}$, Murillo et al., 1999), probably increased by the intense dust contamination during the early cleaning-up operations to remove the sludge.

Cadmium is a trace element of particular interest in this study because sunflower tends to accumulate it more than do other crops. Cd accumulation in spill-polluted plants was significantly greater, in every organ, than in non-polluted plants, at both seedling (V4) and mature (R8) stages (Table 4 and Table 5). However, those values are within the normal range for plants; $100-1000 \mu \mathrm{g} \mathrm{kg}^{-1}$, according to Chaney (1989). This low uptake and accumulation of $\mathrm{Cd}$ by polluted sunflower contradicts the generally accepted pattern of its high transfer coefficient between plant and soil, approximately 100-fold those of $\mathrm{As}$ and $\mathrm{Pb}$ (Kloke et al., 1984).

Total uptake of Cd by the plant was significantly greater in the spill-polluted soil than under nonpolluted conditions (Fig. 3). In contrast to the case of As, plants accumulated more $\mathrm{Cd}$ in shoots than in roots (Fig. 3).

Seeds in polluted plants had a higher Cd concentration than those in non-polluted plants, but the mean value $\left(239 \mu \mathrm{g} \mathrm{kg}^{-1}\right)$ was still below the toxicity level for livestock $\left(500 \mu \mathrm{g} \mathrm{kg}^{-1}\right.$, Chaney, 1989) and the threshold recommended for human nutrition (1000 $\mu \mathrm{g} \mathrm{kg}^{-1}$, Hapke, 1996). Seeds collected from the directly flooded plants in 1998 (1st scenario) had a similar $\mathrm{Cd}$ concentration (mean of $241 \mu \mathrm{g} \mathrm{kg}^{-1}$, Murillo et al., 1999). In both scenarios, seeds of polluted sunflower plants had relatively low $\mathrm{Cd}$ concentration, when compared with a comprehensive screening of 200 
sunflower lines cultivated in non-contaminated soils, which gave a range between 310 and 1340 $\mu \mathrm{g} \mathrm{kg}^{-1}$ (Blamey et al., 1997).

Leaves and stems accumulated less $\mathrm{Cd}$ in the plants cultivated in polluted and remediated soils (2nd scenario) than in spill-flooded plants (1st scenario) (mean of $123 \mu \mathrm{g} \mathrm{kg}^{-1}$ in stems of 2ndscenario plants compared with $278 \mu \mathrm{g} \mathrm{kg}^{-1}$ in 1st-scenario plants) (Murillo et al., 1999). The removal of sludge and remediation of soils can be expected to have diminished the level of $\mathrm{Cd}$ pollution in 2 years. However, it should be borne in mind that the cultivated sunflower varieties were different and could differ in $\mathrm{Cd}$ uptake. Furthermore, they were grown under different conditions: emerging plantlets in normal soils were subjected to a sudden flood by pollutant spill and had to adjust physiologically (1st scenario), whereas plants in the 2nd scenario germinated, emerged and grew in polluted and remediated soils. Finally, during the first year after the spill, sludge removal caused severe dust contamination that could have increased external $\mathrm{Cd}$, in particular on the rugose leaves (Murillo et al., 1999).

Lead was one of the most important polluting elements in the mine spill, and has well-known toxic effects on domestic animals and in humans (Palacios et al., 2002), the sludge contained up to $9700 \mathrm{mg} \mathrm{kg}^{-1}$ (Cabrera et al., 1999). Two years after the mine spill, the availability of $\mathrm{Pb}$ in the polluted and remediated soils of the Guadiamar valley was still considerable (Table 2, Cabrera et al., 2003), despite the cleaning-up and remediation operations carried out. Values of total $\mathrm{Pb}$ in soil (max. of $131 \mathrm{mg} \mathrm{kg}^{-1}$ ) were above the accepted threshold $\left(100 \mathrm{mg} \mathrm{kg}^{-1}\right)$ for toxic effects in plants (Kabata-Pendias and Pendias, 1992).

However, only a fraction of the available $\mathrm{Pb}$ in the soil is taken up by most plants, moreover, most of the $\mathrm{Pb}$ taken up is accumulated in the roots and not translocated into above-ground parts. That is, entry of $\mathrm{Pb}$ into the food web tends to be impeded by the 'soil-plant barrier' (Chaney, 1989), thus preventing the contamination of animals feeding on leaves and fruits.

Spill-polluted plants had higher $\mathrm{Pb}$ concentration in roots, stems and leaves, at both seedling (V4) and mature (R8) stages, than did non-polluted plants (Table 4 and Table 5). At the seedling stage, $\mathrm{Pb}$ concentration in roots, stems and leaves was in the proportion $8: 2: 1$, and at the mature stage, 11:1:3. Therefore, sunflower roots accumulated more $\mathrm{Pb}$ than did above-ground parts, although there was still some translocation and accumulation into mature plant leaves and, especially, seedling stems.

On the other hand, there was no significant accumulation of $\mathrm{Pb}$ in seeds, flower heads and leaf petioles (compared with non-polluted plants, Table $5)$. For these organs, the soil-plant barrier for nonessential $\mathrm{Pb}$ seemed effective. Seeds of polluted plants had relatively low $\mathrm{Pb}$ concentration (mean of $219 \mu \mathrm{g} \mathrm{kg}^{-1}$ ), far below the suggested toxicity level for livestock (30000 $\mu \mathrm{g} \mathrm{kg} \mathrm{kg}^{-1}$, Chaney, 1989) and the more conservative threshold value (3000 $\mu \mathrm{g} \mathrm{kg}^{-1}$ ) accepted as safe for human consumption (Hapke, 1991). Considering only the seeds, as the edible part of this crop, there was no risk of $\mathrm{Pb}$ toxicity from sunflower cultivated in the spill-polluted and remediated soils. Nevertheless, at ecosystem level, roots (with a maximum value of $17270 \mu \mathrm{g} \mathrm{kg}^{-1}$ ) and leaves (with a maximum of $2780 \mu \mathrm{g} \mathrm{kg}^{-1}$ ) of those plants could be toxic to small herbivores, (e.g. insects, worms and hares) feeding on them.

The total $\mathrm{Pb}$ uptake by polluted plants was almost equally distributed between roots and shoots (Fig. 3), unlike As, which concentrated preferentially in roots, and Cd, in shoots (Fig. 3). Although, the $\mathrm{Pb}$ concentration was lower in shoots (one-eleventh that in roots, see above), the higher biomass allocated to the aboveground parts equalled the total uptake.

Plants directly flooded by the mine spill in 1998 (1st scenario) also translocated small amounts of $\mathrm{Pb}$ to the seeds (mean concentration of $423 \mu \mathrm{g}$ $\mathrm{kg}^{-1}$ ). However, the concentration of $\mathrm{Pb}$ measured in leaf blades was relatively high (mean of 7551 $\mu \mathrm{g} \mathrm{kg}^{-1}$ ), probably a reflection of internal tissue content plus external contamination by the intense dust caused by the early clean-up operations of the soil (Murillo et al., 1999).

Thallium was present at a high level in the sludge (approx. $60 \mathrm{mg} \mathrm{kg}^{-1}$, Cabrera et al., 1999), and its concentration in polluted soil was also relatively high (approx. $1 \mathrm{mg} \mathrm{kg}^{-1}$, Murillo et al., 
1999). Polluted plants accumulated more $\mathrm{Tl}$ in every organ, at both seedling (V4) and mature (R8) stages, than did non-polluted plants (Tables 4 and 5). In particular, stems and roots of seedlings had 12-fold higher $\mathrm{Tl}$ concentration than equivalent organs in non-polluted plants (Table 4). The translocation of $\mathrm{Tl}$ in mature plants produced a decreasing concentration from roots/stems/seeds in the proportion 35:10:1 (Table 5), leaf values were similar to those of stems. The total content of $\mathrm{Tl}$ in the spill-polluted plants was distributed more in shoots than in roots (Fig. 3), the higher (three-fold) $\mathrm{Tl}$ concentration in roots was compensated by the greater biomass allocation to shoots.

Seeds of the polluted plants (the edible part of this crop) had very low $\mathrm{Tl}$ concentration (mean of $9.33 \mu \mathrm{g} \mathrm{kg}^{-1}$ ). This value is far below the accepted toxicity thresholds, e.g. $500 \mu \mathrm{g} \mathrm{kg}^{-1}$ of dry matter to feed domestic animals, or $1000 \mu \mathrm{g}$ $\mathrm{kg}^{-1}$ in the diet to prevent $\mathrm{Tl}$ accumulation in animals (Hapke, 1991), and $2500 \mu \mathrm{g} \mathrm{kg}^{-1}$ dry matter of plant tissue as safe value for the food chain (Makridis and Amberger, 1996).

Plants directly affected by the mine spill in 1998 (1st scenario) had even lower $\mathrm{Tl}$ concentration in seeds (mean of $1.7 \mu \mathrm{g} \mathrm{kg}^{-1}$ ), although concentrations in leaves and stems were similar between 1st- and 2nd-scenario plants (see Murillo et al., 1999). The differences in seed composition are probably a reflection of the different sunflower variety used and the different growing conditions in the two scenarios.

The transfer coefficient between plant and soil for $\mathrm{Tl}$ is generally considered to be high (Kloke et al., 1984). However, the significant accumulation of $\mathrm{Tl}$ in roots showed the effectiveness of the soil-plant barrier mechanism for this element. Other authors (Vidal et al., 1999) have noted the low mobility of $\mathrm{Tl}$ in the Guadiamar sludge and contaminated soils, and in consequence, it would have low uptake by plants. The total uptake of $\mathrm{Tl}$ was certainly low (under extreme conditions of $\mathrm{Tl}$ availability, plants can accumulate $\mathrm{Tl}$ up to 100 mg kg-1 (ash weight basis), Kabata-Pendias and Pendias, 1992). At the same time, the soil-plant barrier effectively reduced (35-fold) the translocation of $\mathrm{Tl}$ from roots to seeds. There is a general system of physiological barriers impeding metal translocation to seeds during their maturation (Ernst et al., 1992).

\subsection{Use of sunflower for phytoremediation}

Sunflower has been cited as a suitable crop for the cleaning up of soils polluted by Zn (Van der Lelie et al., 2001). However, the potential for phytoextraction of trace elements (by high accumulation in harvestable shoot tissues) in the cultivated sunflower plants studied here was very low. According to our results (see Fig. 3), it would be possible to extract approximately $2.05 \mathrm{~kg} \mathrm{Zn}$ $\mathrm{ha}^{-1}$ year $^{-1}$ from the contaminated soil by harvesting and removing the sunflower shoots. (That could be increased to $2.14 \mathrm{~kg} \mathrm{Zn} \mathrm{ha}^{-1}$ year $^{-1}$ if the complete plant, with roots, were harvested.) Such amounts of $\mathrm{Zn}$ extracted yearly (sunflower is an annual crop) are negligible in comparison to the magnitude of $\mathrm{Zn}$ contamination in the soil, i.e. approximately $705 \mathrm{~kg} \mathrm{ha}^{-1}$ of total $\mathrm{Zn}$ in the top layer $(0-25 \mathrm{~cm})$ of the spill-polluted soil, which exceeds by more than $500 \mathrm{~kg} \mathrm{ha}^{-1}$ the total $\mathrm{Zn}$ in normal, non-polluted soils.

The extraction of potentially toxic elements, such as $\mathrm{As}$ and $\mathrm{Pb}$, by the above-ground part of the crop was even more negligible. It would be possible to extract approximately $0.003 \mathrm{~kg} \mathrm{ha}^{-1}$ year ${ }^{-1}$ of As and $0.016 \mathrm{~kg} \mathrm{ha}^{-1}$ year $^{-1}$ of $\mathrm{Pb}$, the loads remaining in the spill-polluted soil were approximately $186 \mathrm{~kg} \mathrm{ha}^{-1}$ of As and $280 \mathrm{~kg}$ $\mathrm{ha}^{-1}$ of $\mathrm{Pb}(0-25-\mathrm{cm}$ depth $)$ in excess of the corresponding amounts in the non-polluted soil.

Plants can be used to remediate polluted soils by mechanisms other than phytoextraction. The prompt restoration of a dense vegetation cover is the most useful and widespread method to stabilise mine wastes physically and to reduce effects of metal pollution (Bargagli, 1998). Native plant species able to tolerate soil pollution are the best choice. In the Guadiamar valley, spill-affected lands have been compulsorily purchased by the regional administration to establish a 'Green Corridor', using native trees and shrubs (Junta de Andalucía, 2001). Native wild plants that quickly colonise abandoned croplands in remediated soils, such as Bermuda grass (Cynodon dactylon) and wild sorghum (Sorghum halepense), have been 
suggested as suitable plants for soil stabilisation (Madejón et al., 2002).

In other cases of soil pollution by heavy metals, several common agricultural and horticultural crops have been indicated for phytostabilisation (Saxena et al., 1999). We suggest that sunflower can be used for remediation procedures in metalcontaminated soils. It is a fast-growing crop which would favour soil stabilisation. Its tough leaves and stems are rarely eaten by animals. The seeds (actively eaten by birds) have very low concentrations of potentially toxic elements, and represent low risk for the food web. Additionally, the eventual seed harvesting and oil production (used for industrial purposes) could reduce the net cost of the remediation task.

\section{Acknowledgments}

This study was carried out in the framework of the 'Programa de Investigación del Corredor Verde (PICOVER)', supported with funds of the 'Consejería de Medio Ambiente' of the Regional Government (Junta de Andalucía), Spain. We thank J.M. Alegre for help in sampling and Juan Maranón for providing facilities at Soberbina farm for cropping sunflower. Trace element concentrations in plants were determined in the Centre for Scientific Instrumentation (Dr O. Cazalla, University of Granada).

\section{References}

Ayora C, Barettino D, Carrera J, Manzano M, Mediavilla C, editors. Las aguas y los suelos tras el accidente de Aznalcóllar. Bol Geol Minero 2001;112:1-294.

Bargagli R. Trace elements in terrestrial plants. An ecophysiological approach to biomonitoring and biorecovery. Berlin: Springer-Verlag, 1998. p. 324.

Blamey FPC, Zollinger RK, Schneiter AA. Sunflower production and culture. In: Schneiter AA, editor. Sunflower technology and production. Madison, USA: ASA, 1997. p. 595670 .

Bowen HJM. Environmental chemistry of the elements. London: Academic Press, 1979. p. 333.

Cabrera F, Clemente L, Díaz Barrientos E, López R, Murillo JM. Heavy metal pollution of soils affected by the Guadiamar toxic flood. Sci Total Environ 1999;242:117-129.

Cabrera F, Clemente L, Cordón R, Hurtado MD, López R, Madejón P, Marañón T, Moreno F, Murillo JM, Nagel I. Heavy metals pollution in soils of the Guadiamar River
Valley. In: Del Valls A, Blasco J, editors. Integrated Assessment and Management of the Ecosystems Affected by the Aznalcollar Mining Spill (SW, Spain). IOC/ICAM/ UNESCO Technical Report, 2003 (in press).

Chaney RL. Toxic element accumulation in soils and crops: protecting soil fertility and agricultural food-chains. In: BarYosef B, Barrow NJ, Goldshmid J, editors. Inorganic contaminants in the Vadose Zone. Berlin: Springer-Verlag, 1989. p. $140-158$.

Ernst WHO, Verkleij JAC, Schat H. Metal tolerance in plants. Acta Bot Neerl 1992;41:229-248.

Galán E, González I, Fernández-Caliani JC. Residual pollution load of soils impacted by the Aználcollar (Spain) mining spill after clean-up operations. Sci Total Environ 2002;286:167-179.

Griepink B, Muntau H. The certification of the contents (mass fractions) of As, B, Cd, Cu, Hg, Mn, Mo, Ni, Pb, Sb, Se and $\mathrm{Zn}$ in rye grass, CRM 281, Report no. EUR $11839 \mathrm{EN}$. Luxembourg, 1987.

Griepink B, Muntau H. The certification of the contents (mass fractions) of arsenic, cadmium, copper, lead, selenium and zinc in a sea lettuce (Ulva lactuca), CRM No. 279, Report no. 11185 EN., Luxembourg, 1988.

Grimalt JO, Ferrer M, Macpherson E. The mine tailing accident in Aznalcollar. Sci Total Environ 1999;242:3-11.

Haby VA, Russelle MP, Skogley EO. Testing soils for potassium, calcium and magnesium. In: Westerman RL, editor. Soil testing and plant analysis. Madison, Wisconsin: Soil Science Society of America, 1990. p. 181-227.

Hapke HJ. Metal accumulation in the food chain and load of feed and food. In: Merian E, editor. Metals and their compounds in the environment. Occurrence, analysis, and biological relevance. New York: Weinheim, 1991. p. 469479.

Hapke HJ. Heavy metal transfer in the food chain to humans. In: Rodríguez-Barrueco C, editor. Fertilizers and Environment. Dordrecht: Kluwer, 1996. p. 431-436.

Junta de Andalucía. Corredor Verde del Guadiamar, Abril 1998-Abril 2001. Consejería de Medio Ambiente de la Junta de Andalucía. Sevilla, 2001, pp 70.

Kabata-Pendias A, Pendias H. Trace elements in soils and plants. Boca Raton, Florida: CRC Press, 1992. p. 365.

Kamnev AA, Van der Lelie D. Chemical and biological parameters as tools to evaluate and improve heavy metal phytoremediation. Biosci Rep 2000;20:239-258.

Kloke A, Sauerbeck DR, Vetter H. The contamination of plants and soils with heavy metals and the transport of metals in terrestrial food chains. In: Nriagu JO, editor. Changing metal cycles and human health. Berlin: Springer-Verlag, 1984. p. $113-141$.

López-Pamo E, Barettino D, Antón-Pacheco C, Ortiz G, Aránz JC, Gumiel JC, Martínez-Pledel M, Aparicio O, Montouto O. The extent of the Aznalcóllar pyritic sludge spill and its effects on soils. Sci Total Environ 1999;242:57-88.

Madejón P, Murillo JM, Marañón T, Cabrera F, López R. Bioaccumulation of $\mathrm{As}, \mathrm{Cd}, \mathrm{Cu}, \mathrm{Fe}$ and $\mathrm{Pb}$ in wild grasses 
affected by the Aznalcóllar mine spill (SW Spain). Sci Total Environ 2002;290:105-120.

Makridis $\mathrm{CH}$, Amberger A. Thallium concentration in soils and crops and critical values with respect to food chain. In: Rodríguez-Barrueco C, editor. Fertilizers and environment. Dordrecht: Kluwer, 1996. p. 443-448.

Marschner H. Mineral nutrition of higher plants. London: Academic press, 1995. p. 889.

Mathers AC, Stewart BA. Sunflower nutrient uptake, growth, and yield as affected by nitrogen or manure, and plant population. Agron J 1982;74:911 -915.

Murillo JM, Marañón T, Cabrera F, López R. Accumulation of heavy metals in sunflower and sorghum plants affected by the Guadiamar spill. Sci Total Environ 1999;242:281292.

Palacios H, Iribarren I, Olalla MJ, Cala V. Lead poisoning of horses in the vicinity of a battery recycling plant. Sci Total Environ 2002;290:81-89.

Rengel Z. Mechanism of plant resistance to toxicity of aluminium and heavy metals. In: Basra AS, Basra RK, editors. Mechanisms of environmental stress resistance in plants. Amsterdam: Harwood Academic Publishers, 1997. p. $241-$ 276.

Reuter DJ, Robinson JB. Plant analysis. An interpretation manual. Collingwood, Australia: CSIRO Publishing, 1997. p. 572.
Saxena PK, KrishnaRaj S, Dan T, Perras MR, Vettakkorumakankav NN. Phytoremediation of heavy metal contaminated and polluted soils. In: Prasad MNV, Hagemeyer J, editors. Heavy metal stress in plants. From molecules to ecosystems. Berlin: Springer-Verlag, 1999. p. 305-329.

Schneiter AA, Miller JF. Description of sunflower growth stages. Crop Sci 1981;21:901-903.

Simón M, Ortiz I, García I, Fernández E, Fernández J, Dorronsoro C, Aguilar J. Pollution of soils by the toxic spill of a pyrite mine (Aznalcóllar, Spain). Sci Total Environ 1999;242:105-115.

Sing HG, Sahu MP. Response of oilseeds to sulfur. Fert News 1986;31:23-30.

Smith E, Naidu R, Alston AM. Arsenic in the soil environment: a review. Adv Agron 1998;64:149-195.

SPSS for Windows. ${ }^{\circ}$ SPPS Inc., (1989-1999), Headquarters, Illinois, USA.

Van der Lelie D, Schwitzguébel JP, Glass DJ, Vangronsveld J, Baker A. Assessing phytoremediation's progress in the United States and Europe. Environ Sci Technol 2001;35:447-452.

Vidal M, López-Sánchez JF, Sastre J, Jiménez G, Dagnac T, Rubio R, Rauret G. Prediction of the impact of the Aznalcóllar toxic spill on the trace element contamination of agricultural soils. Sci Total Environ 1999;242:131-148. 